\title{
Tindak Tutur dalam Acara Debat Calon Presiden Republik Indonesia 2019
}

\author{
Haryadi Yanto ${ }^{1 凶}$, Ratu Wardarita ${ }^{2}$, Arif Ardiansyah ${ }^{3}$ \\ (1) Sekolah Menengah Pertama Negeri 2 Rambang Muara Enim \\ $(2,3)$ Universitas PGRI Palembang
}

$\square$ Corresponding author

[haryadiyanto2006@gmail.com]

\begin{abstract}
Abstrak
Penelitian ini bertujuan untuk mengetahui tindak tutur asertif, direktif, komisif, ekspresif, deklaratif dan manakah tindak tutur yang dominan yang digunakan oleh calon Presiden Republik Indonesia dalam Acara Debat Calon Presiden Republik Indonesia 2019 Ir. H. Joko Widodo dan H. Prabowo Subianto. Metode penelitian ini menggunakan metode kualitatif. Sumber datanya adalah Acara Debat Calon Presiden Republik Indonesia 2019 Ir. H. Joko Widodo dan H. Prabowo Subianto, 17 Februari 2019. Teknik pengumpulan data menggunakan rekaman video dan dokumentasi. Analisis data menggunakan model analisis interaktif. Hasil penelitian ini menunjukkan bahwa: (1) tindak tutur asertif dalam Acara Debat Calon Presiden Republik Indonesia 2019 Ir. H. Joko Widodo dan H. Prabowo Subianto ditemui pada kata-kata: membahas, dikatakan, mengatakan, berkaitan, bermanfaat, dilakukan, lompatan besar, mengurangi; (2) tindak tutur direktif pada kata-kata tidak bisa, saya kira, terima kasih, coba kita lihat sekarang, kita bisa manfaatkan; (3) tindak tutur komisif pada kalimat: kita harus sungguh-sungguh membangun suatu kemandirian, nanti insya Allah dapat mandat dari rakyat kami akan menjamin pangan tersedia; (4) tindak tutur ekspresif pada kata-kata: majelis yang terhormat, bisa memenuhi pangan untuk rakyatnya, energi untuk rakyatnya; (5) tindak tutur deklaratif pada kata-kata: 2017 telah kita bagikan 5 juta sertifikat kepada rakyat dibawah; dan (6) jenis tindak tutur yang dominan digunakan adalah tindak tutur asertif.
\end{abstract}

Kata Kunci: tindak tutur asertif; direktif; komisif; ekspresif; deklaratif

\begin{abstract}
This study aims to determine which speech acts are assertive, directive, commissive, expressive, declarative and which are the dominant speech acts used in the 2019 Presidential Candidate Debate Event for the President of the Republic of Indonesia, Ir. H. Joko Widodo and H. Prabowo Subianto. This research method uses qualitative methods. The data source is the 2019 Presidential Candidate Debate Event for the President of the Republic of Indonesia, Ir. H. Joko Widodo and H. Prabowo Subianto, 17 February 2019. Data collection techniques used video recordings and documentation. Data analysis using an interactive analysis model. The results of this study indicate that: (1) assertive speech acts in the 2019 Presidential Candidate Debate Event for the Republic of Indonesia Ir. H. Joko Widodo and H. Prabowo Subianto were met in words: discussing, being said, saying, related, useful, carried out, big leaps, reducing; (2) the directive speech act on words cannot, I think, thank you, let's see now, we can use it; (3) a commissive speech act in the sentence: we have to really build a sense of independence, God willing, we will get a mandate from our people to ensure food is available; (4) expressive speech acts on words: honorable assembly, able to provide food for its people, energy for its people; (5) declarative speech acts on words: 2017 we have distributed 5 million certificates to the people below; and (6) the dominant type of speech act used is assertive speech acts.
\end{abstract}

Keyword: assertive; directive; commissive; expressive; declarative speech acts

\section{PENDAHULUAN}

Manusia sebagai makhluk sosial tidak bisa lepas dari lingkungan masyarakat yang saling berdampingan dalam berinteraksi antar masyarakat sekitar. Semakin banyak kita beriteraksi dengan masyarakat maka semakin banyak pula ilmu yang kita dapatkan. Alat interaksi yang paling utama adalah bahasa. Setiap manusia pasti menggunakan bahasa dalam berinteraksi dengan sesama manusia lainnya. Dalam kehidupan sehari-hari tentunya manusia tidak akan lepas dari hubungan antara satu dengan yang lainnya, manusia itu pastinya akan mencari individu atau kelompok untuk saling berinteraksi atau bertukar pikiran.

Bahasa sebagai alat komunikasi yaitu sarana penyampaian informasi kepada orang lain secara lisan maupun tulis mengenai apapun yang ingin kita sampaikan agar orang dapat mengerti maksud dan tujuan yang 
kita inginkan tanpa menghindari tata bahasa yang sudah ada. Dalam bentuk tulis, bahasa bisa ditemukan dalam bentuk wacana. Sedangkan secara lisan, bahasa dapat digunakan dalam kegiatan berbicara, baik satu arah maupun dua arah.

Bahasa digunakan dalam proses komunikasi sosial di masyarakat, baik oleh individu dengan individu, individu dengan kelompok, maupun kelompok dengan kelompok. Selain itu, bahasa juga dipakai untuk mengungkapkan emosi manusia, baik itu emosi positif yang berupa ungkapan rasa bahagia, dan juga emosi negatif yang berupa ungkapan sedih, marah, dan murung.

Menurut Chaer dan Agustina, (2010:11) fungsi utama bahasa adalah sebagai alat komunikasi atau alat interaksi. Melalui kegiatan berkomunikasi setiap penutur hendak menyampaikan tujuan atau maksud tertentu kepada mitra tutur. Komunikasi yang terjadi harus berlangsung secara efektif dan efisien, sehingga pesan yang disampaikan dapat dipahami dengan jelas oleh mitra tutur yang terlibat dalam proses komunikasi. Proses komunikasi yang efektif dan efesien tidak akan terjadi dengan baik, apabila bahasa yang digunakan oleh penutur tidak mampu dipahami oleh mitra tutur. Dengan demikian, tindak tutur yang baik dalam berkomunikasi dengan orang lain, membutuhkan kecerdasan berbahasa yang baik.

Salah satu yang menjadi bagian dari bahasa sebagai alat komunikasi yaitu tuturan. Tuturan yaitu setiap kata atau frasa yang diucapkan oleh penutur. Dalam berkomunikasi, setiap tuturan pasti memiliki makna, baik itu tersurat maupun tersirat. Pemilihan kata-kata yang tepat sangat diperlukan dalam bertutur supaya maksud dalam berkomunikasi dapat tercapai.

Sumarsono (dikutip Oktaria, 2016:2) tindak tutur adalah tuturan dari seseorang yang bersifat psikologis dan yang dilihat dari makna tindakan dari tuturannya itu. Tindak termasuk pada sebuah tindakan karena di dalam bertutur setiap individu dapat melakukan sesuatu sesuai dengan tujuannya dalam bertutur. Pada saat bertutur terkadang kita memberikan saran kepada lawan bicara, berjanji, mengundang, meminta, dan melarangnya untuk melakukan sesuatu sesuai dengan yang diinginkan. Semua maksud tersebut dapat tercapai apabila dalam bertutur, menggunakan strategi yang tepat seperti penggunaan bahasa yang lugas, jelas, dan tepat sehingga lawan bicara memberikan keterangan atau informasi yang jelas tentang dirinya.

Menurut Mangkunegara (2010:2), Sikap merupakan faktor yang sangat menentukan perilaku, karena sikap adalah adalah kecenderungan bertindak atau tidak terhadap suatu objek. Sikap juga merupakan kesiapan mental yang diorganisasikan lewat pengalaman yang mempunyai pengaruh kepada tanggapan seorang terhadap orang lain dan situasi yang berhubungan dengannya.

Tuturan dalam berkomunikasi juga harus memenuhi delapan komponen tutur, komponen tutur ini sering disingkat dengan SPEAKING (Hymes,1989:54-62). Kedelapan komponen tutur tersebut yaitu, Situation (latar waktu dan tempat), participants (peserta tutur), ends (tujuan), Acts (bentuk dan Isi tuturan), Key (nada dan intonasi), Instrumentality (alat yang digunakan), Norms (norma), dan Genres (bentuk tuturan).

Pada tahun 2019 bangsa Indonesia melaksanakan pesta demokrasi untuk pemilihan Presiden Republik Indonesia Periode 2019-2024. Adapun calon Presiden yang mengikuti pemilihan Presiden terdiri atas dua calon Ir. H. Joko Widodo dan H. Prabowo Subianto.

Dalam acara debat calon presiden, tentunya para calon presiden harus dapat berbahasa dengan baik, lugas, dan tepat sehingga lawan bicara memberikan keterangan atau informasi yang jelas tentang dirinya. Tuturan selain berwujud janji-janji, harapan-harapan dapat pula berupa sindiran, serangan atau kritikan terhadap lawan bicara.

Berdasarkan uraian di atas maka penelitian yang berjudul "Tindak Tutur dalam acara Debat Calon Presiden Republik Indonesia 2019 Ir. H. Joko Widodo dan H. Prabowo Subianto", perlu diteliti. Karena tuturan yang disampaikan oleh calon presiden memiliki pengaruh dalam meyakinkan pilihan masyarakat Indonesia untuk memilih calon presiden tersebut

\section{METODE PENELITIAN}

Metode penelitian ini adalah deskriptif kualitatif dengan teknik analisis interaktif. Objek dalam penelitian ini adalah tuturan dari calon Presiden Republik Indonesia yaitu Ir. H. Joko Widodo dan H. Prabowo Subianto.

\section{HASIL DAN PEMBAHASAN}

Penelitian ini dilakukan pada stasiun televisi Kompas TV dalam acara debat kedua calon Presiden Republik Indonesia Februari 2019. Penelitian ini dilakukan untuk mengetahui tindak tutur asertif, direktif, komisif, ekspresif, deklaratif, dan jenis tindak tutur yang dominan yang digunakan dalam acara "Debat Calon Presiden Republik Indonesia 2019 Ir. H. Joko Widodo dan H. Prabowo Subianto" pada stasiun televisi Kompas TV pada debat kedua Februari 2019.

Jenis Tindak Tutur Dominan yang Digunakan dalam Acara Debat Calon Presiden Republik 2019 Ir. H. Joko Widodo dan H. Prabowo Subianto 
Berdasarkan data yang sudah dipaparkan dalam analisis data di atas dapat diketahui jenis tindak tutur yang dominan digunakan dalam acara Debat Calon Presiden Republik 2019 Ir. H. Joko Widodo dan H. Prabowo Subianto adalah tindak tutur asertif. Untuk lebih jelasnya dapat dilihat pada tabel 1.

\section{Tabel 1. Jenis Tindak Tutur yang Muncul dalam Debat Calon Presiden Republik 2019 Ir. H. Joko Widodo dan H. Prabowo Subianto}

\begin{tabular}{cccccc}
\hline $\begin{array}{c}\text { Acara Debat } \\
\text { Ke 2 }\end{array}$ & Asertif & Direktif & $\begin{array}{c}\text { Tindak Tutur } \\
\text { Komisif }\end{array}$ & Ekspresif & Deklaratif \\
\hline 17 Februari 2019 & 126 & 22 & 46 & 48 & 19 \\
Jumlah & 126 & 22 & 46 & 48 & 19 \\
\hline
\end{tabular}

Tindak Tutur Asertif dalam Acara Debat Calon Presiden Republik 2019 Ir. H. Joko Widodo dan H. Prabowo Subianto

Tindak tutur asertif terikat pada kebenaran proposisi yang diungkapkan penuturnya (Murtaningsih, 2013:11). Dari data yang telah didapat dari debat kedua terdapat 126 (seratus dua puluh enam) tindak tutur asertif yang disampaikan oleh para calon Presiden Republik Indonesia 2019 Ir. H. Joko Widodo dan H. Prabowo Subianto. Berikut contoh kata-kata yang menunjukkan tindak tutur asertif : Membahas, dikatakan, mengatakan, lompatan besar, mengurangi, kita lakukan, memperbaiki, dilaksanakan, dimanfaatkan, disampaikan dan sebagainya. Kata-kata tersebut merupakan contoh kata asertif dalam sebuah kalimat PPB sekarang mengatakan bahwa inilah 3 (tiga) masalah yang utama tolak ukur Keberhasilan suatu negara.

\section{Tindak Tutur Direktif dalam Acara "Debat Calon Presiden Republik 2019 Ir. H. Joko Widodo dan H. Prabowo Subianto"}

Tindak tutur direktif bertujuan menghasilkan suatu efek berupa tindakan yang dilakukan oleh penutur Searle dikutip Leech, 1993:164. Dari data yang telah didapat pada debat ke dua, terdapat terdapat 22 (dua puluh dua) tindak tutur direktif yang disampaikan oleh para calon Presiden Republik Indonesia 2019 Ir. H. Joko Widodo dan H. Prabowo Subianto. Tindak tutur direktif dalam penelitian ini dapat ditemui pada kata yaitu: Tidak bisa, Coba kita lihat sekarang, membuka kesempatan petani-petani kita untuk melompat dalam berproduksi, kita bisa manfaatkan, kita juga koreksi, perlu ada investigasi lanjutan, pelanggaran lingkungan hidup banyak sekali dilakukan dan masih merupakan PR bagi kita semua.

\section{Tindak Tutur Komisif dalam Acara Debat Calon Presiden Republik 2019 Ir. H. Joko Widodo dan H. Prabowo Subianto}

Tindak tutur komisif terikat pada suatu tindakan di masa depan (Ibrahim, 1993:16). Dari data yang telah didapat dari debat kedua terdapat 46 (empat puluh enam) tindak tutur komisif yang disampaikan oleh para calon Presiden republik Indonesia 2019 Ir. H. Joko Widodo dan H. Prabowo Subianto. Tindak tutur komisif dalam penelitian ini terdapat pada kata-kata yaitu: kita harus sungguh-sungguh membangun suatu kemandirian, kami akan menjamin pangan tersedia, nelayan harus mendapatkan imbalan penghasilan yang memadai, Kami juga akan segera turunken harga listrik, kita akan mengamankan sumber-sumber ekonomi, saya mengajak marilah kita bersama-sama mencari pemecahan masalah, saya menawarkan suatu strategi, Visi kami adalah Indonesia maju, dan sebagainya.

\section{Tindak Tutur Ekspresif dalam Acara Debat Calon Presiden Republik 2019 Ir. H. Joko Widodo dan H. Prabowo Subianto}

Tindak tutur ekspresif berfungsi untuk mengungkapkan atau mengutarakan sikap psikologis penutur terhadap keadaan yang tersirat (lihat Searle dikutip Leech, 1993:164).. Dari data yang telah didapat pada debat kedua, terdapat 48 (empat puluh delapan) tindak tutur ekspresif yang disampaikan oleh para calon Presiden Republik Indonesia 2019 Ir. H. Joko Widodo dan H. Prabowo Subianto. Tindak tutur ekspresif yang digunakan ditemukan pada penelitian ini seperti: majelis yang terhormat, Assalamualaikum Wr. Wb, selamat malam dan salam sejahtera, saya ingin mengucapkan terima kasih, kita ingin kebakaran hutan, kebakaran lahan gambut tidak terjadi lagi, dan sebagainya.

\section{Tindak Tutur Deklaratif dalam Acara Debat Calon Presiden Republik 2019 Ir. H. Joko Widodo dan H. Prabowo Subianto}

Tindak tutur deklaratif ini akan mengakibatkan adanya kesesuaian antara isi proposisi dengan realitas, (Searle dikutip Leech, 1993:164). Dari data yang telah didapat pada debat kedua, terdapat 19 (Sembilan belas) tindak tutur deklaratif yang disampaikan oleh para calon Presiden Republik Indonesia 2019 Ir. H. Joko Widodo dan H. Prabowo Subianto. 
Tindak tutur deklaratif yang digunakan ditemukan pada penelitian ini seperti: kita tahu dalam tiga tahun ini telah kita gelontorkan 187 triliun dana desa di desa-desa apa yang kita dapatkan dari dana iini telah dibangun $191.000 \mathrm{~km}$ jalan di desa, 58.000 unit irigasi yang telah kita bangun dari dana desa, tahun 2018 kita hanya import 180.000 ton jagung artinya ada produksi 3,3 juta ton yang telah dilakukan petani, Kita telah bangun yang palapa ring di Indonesia bagian barat telah $100 \%$ kita selesaikan. Indonesia bagian tengah telah $100 \%$ telah kita selesaikan, dan sebagainya.

\section{SIMPULAN}

Menurut peneliti dari kelima tuturan yaitu, asertif, direktif, komisif, ekspresif dan deklaratif yang dominan digunakan oleh penutur yaitu Ir, H. Joko Widodo dan H. Prabowo Subianto dalam penelitian ini berupa tindak tutur asertif karena apa diungkapkan oleh penutur dan mitra tutur mengandung makna kebenaran dan fakta yang benar-benar terjadi dalam ruang lingkup sosial yang terjadi di masayarakat, khususnya masyarakat di Indonesia..

\section{UCAPAN TERIMA KASIH}

Terima kasih yang sebesar-besarnya kami ucapkan kepada teman-teman dan semua pihak yang banyak membantu kami dalam menyelesaikan artikel ini sehingga dapat dipublikasikan.

\section{DAFTAR PUSTAKA}

Chaer, A., \& Agustina, L. (2010). Sosiolinguistik Perkenalan Awal. Jakarta: Rineka Cipta.

Ibrahim, A. S. (1993). Kajian Tindak Tutur. Surabaya: Usaha Nasional.

Leech, G. (1993). Prinsip-Prinsip Pragmatik. Jakarta: UI-Press

Mangkunegara, Anwar Prabu. (2010). Perilaku dan Budaya Organisasi. Bandung: Remaja Roasdakarya.

Murtianingsih. (2013). Sosiolinguistik Suatu Pengantar. Bandung: Alfabeta

Sumarsono. (2014). Sosiolinguistik. Yogyakarta: Pustaka Pelajar 